International Research Journal of Management, IT \& Social Sciences
Available online at https://sloap.org/journals/index.php/irjmis/
Vol. 7 No. 3, May 2020, pages: 104-109
$\begin{aligned} & \text { ISSN: 2395-7492 } \\ & \text { https://doi.org/10.21744/irjmis.v7n3.926 }\end{aligned}$

\title{
Mobile Payment Transaction on MSMEs
}

Putu Oka Kusuma ${ }^{\text {a }}$ Gede Sri Darma ${ }^{\text {b }}$

Article history:

Submitted: 27 March 2020

Revised: 09 April 2020

Accepted: 18 May 2020

\section{Keywords:}

mobile payment; perception of comfort; perception of ease; perception of usefulness; social influence;

\begin{abstract}
The rapid development of technology is driving changes in payment systems in transactions. One payment system is a payment system using a smartphone called Mobile Payment. We can pay attention to Mobile Payment service providers in Indonesia starting to target MSMEs as their target market. This is a very appropriate step considering a large number of MSMEs in Indonesia. This study aims to determine the acceptance of Mobile Payment at MSMEs. By investigating the factors that influence the intention to use Mobile Payment. This study uses descriptive qualitative methods and interpretive through observation, documentation, and interviews with informants. The informants in this study were the MSMEs Owner and Managers in Denpasar. Based on the results of the research conducted, it can be concluded that Mobile Payment has not been fully accepted by MSMEs in Denpasar. Consumers use Mobile Payment because they have partnered with the application, if for offline shopping consumers rarely use and use more cash. The results showed the Perception of Usefulness, Perception of Ease, Perception of Comfort, and Social Influence affect the acceptance of Mobile Payment at MSMEs in Denpasar.
\end{abstract}

International research journal of management, IT and social sciences (C) 2020. This is an open access article under the CC BY-NC-ND license (https://creativecommons.org/licenses/by-nc-nd/4.0/).

\section{Corresponding author:}

Putu Oka Kusuma,

Universitas Pendidikan Nasional, Denpasar, Indonesia.

Email address: okakusuma42@gmail.com

a Universitas Pendidikan Nasional, Denpasar, Indonesia

${ }^{\mathrm{b}}$ Universitas Pendidikan Nasional, Denpasar, Indonesia 


\section{Introduction}

Every country has a goal to make changes and evolve so that they can keep up with the times. The world is currently undergoing a fourth revolution, or better known as the 4.0 revolution era, where what happens is the reduced role of human power as an operator but more interaction between machines and machines. The rapid development of technology is driving changes in payment systems in transactions. Mobile phones have provided enormous opportunities for financial development, and are anticipated to be a common tool for carrying out various financial transactions (Iman, 2018).

Table 1

Cellular telephone customers in Indonesian

\begin{tabular}{cc}
\hline Year & User \\
\hline 2013 & 313.226 .914 \\
2014 & 325.582 .891 \\
2015 & 338.948 .340 \\
2016 & 385.573 .398 \\
2017 & 435.193 .605 \\
\hline Source: Central Bureau of Statistics Republic of Indonesia (2017)
\end{tabular}

Based on the table above, it can be seen that the increase in cellular phone subscribers continues to increase from year to year. The growth of cellular phone users is encouraging people to change how to manage primarily finance and this is an opportunity for the financial industry to improve its services by launching internet-based services, such as mobile banking (Pratiwi \& Indriani, 2017). On August 14, 2014 Bank Indonesia (BI) officially launched the National NonCash Movement. The purpose of doing this is to increase public awareness in using non-cash payment facilities in conducting transactions to form a non-cash community or community better known as Less Cash Society (LCS). The National Non-Cash Movement provides benefits in increasing financial efficiency and productivity that can encourage economic growth and increase people's welfare as indicated by increased velocity of money. Non-cash payments may already be familiar, Indonesian people are already familiar with ATM cards, debit cards, and credit cards. Technology in the mobile era one of which is a payment system using a smartphone called Mobile Payment, Mobile Payment can be defined as a device that allows users to make payments using mobile devices including wireless handsets, personal digital assistants (PDAs), radiofrequency devices (RF), and communication-based devices. The development of financial technology (fintech) is based on consumer needs.

Table 2

Electronic money transactions in Indonesia

\begin{tabular}{ccc}
\hline Year & Volume* $^{*}$ & Transactions** \\
\hline 2014 & 203.369 .990 & 3.319 .556 \\
2015 & 535.579 .528 & 5.283 .018 \\
2016 & 683.133 .352 & 7.063 .689 \\
2017 & 943.319 .933 & 12.375 .469 \\
2018 & 2.922 .698 .905 & 47.198 .616
\end{tabular}

(* Volume in transaction units, (** Nominal in millions of Rupiah)

Source: www.bi.go.id

In Table 2, regarding Electronic Money transactions in Indonesia over the past 5 years the increase in the use of electronic money transactions has continued to increase both in terms of volume and nominal. The development of non-cash from year to year has increased, in addition to being supported by technological advances, there has been a change in people's lifestyles and the development of innovations has added to non-cash transactions. In modern times like today, practicality is very important (Lintangsari et al., 2018). For financial needs now a lot of technology can be used for example the development of Mobile Payments.

Kusuma, P. O., \& Darma, G. S. (2020). Mobile payment transaction on MSMEs. International Research Journal of Management, IT and Social Sciences, 7(3), 104-109. https://doi.org/10.21744/irjmis.v7n3.926 
Providers of fintech services, especially Mobile Payment, target MSMEs as their target market. This is a very appropriate step considering the number of MSMEs in Indonesia is increasing every year, as presented in the following table.

Table 3

The MSMEs in Indonesia

\begin{tabular}{lrrrrrr}
\hline Type of & \multicolumn{7}{c}{ Year } \\
\cline { 2 - 7 } business & \multicolumn{1}{c}{2012} & \multicolumn{1}{c}{2013} & \multicolumn{1}{c}{2014} & \multicolumn{1}{c}{2015} & \multicolumn{1}{c}{2016} \\
\hline Micro & 54.559 .969 & 55.856 .176 & 57.189 .393 & 58.521 .987 & 60.863 .578 & 62.106 .900 \\
Small & 602.195 & 629.418 & 654.222 & 681.522 & 731.047 & 757.090 \\
Medium & 44.280 & 48.997 & 52.106 & 59.263 & 56.551 & 58.627 \\
\hline
\end{tabular}

Source: Central Bureau of Statistics Republic of Indonesia (2017)

In the table above it can be seen that every year there is an increase in the number of MSMEs. The empowerment of micro, small, and medium enterprises (MSMEs) in various regions will be a surefire solution to overcome the sluggishness that is currently plaguing the current state of the national economy. This shows that SMEs or MSMEs have a large influence on the Indonesian economy (Slamet et al., 2017). Based on the background explanation above, the researcher is interested to know the acceptance of Mobile Payment at MSMEs

\section{Literature review}

a) Mobile Payment

Mobile Payment is an alternative electronic payment method for goods, services, and bills. This payment method uses mobile devices such as mobile phones, smartphones, personal digital assistants by utilizing wireless communication network technology or other communication technologies such as Bluetooth, radio frequency identification (RFID), and near field communication (NFC). Oliveira et.al added that Mobile Payment and mobile banking are typical systems in the number of players involved; mobile banking is a simple direct relationship between consumers and banks while Mobile Payment is a three-party process between consumers, merchants, and banks. Currently there are additional new parties, namely cellular operators and smartphone manufacturers - such as Apple and Samsung with Apple Pay and Samsung Pay (Oliveira et al., 2016; Zhou, 2013; Mallat, 2007; Lu et al., 2011).

b) Technology Acceptance Model (TAM)

The Technology Acceptance Model developed by Davis (1989), is one of the most popular research models for predicting the use and acceptance of information systems and technology by individual users. The technology acceptance model (TAM) is a model of acceptance of information technology systems that will be used by users.

c) Perception of Ease

Davis (1989), the perception of ease is the level of a person's belief that in its use at some point, it will be free from effort. Free from this effort is meant to be free from difficulties or do not require an effort in using it (Davis, 1989).

d) Perception of Usefulness

The Perception of Usefulness can be interpreted as the degree or level of confidence someone has in using a system that can improve the performance of its users. This refers to the meaning of benefits (useful) which is the ability to be able to provide the maximum benefit (Davis, 1989; Guritno \& Siringoringo, 2013; Blomstermo et al., 2004; Saadé \& Bahli, 2005).

e) Interest in Using

A person's interest can be influenced by several factors such as social factors, feelings (affect), and the consequences of feelings (Safitri, 2015). The increasing interest in using information technology is also based on the perceived benefits of its users (Davis et al., 1989). According to Thompson \& Osella (1991), the greater one's confidence in the benefits of information technology can increase their interest in using information technology to do their jobs. 
f) Perception of Comfort

In the Indonesian Dictionary accessed at https://kbbi.web.id/ nyaman, comfort is fresh, healthy while comfort is comfortable; freshness; coolness. According to Weisman (1981), comfort is an environmental condition that can cause a sense that is following the five senses of the dissertation of facilities that are also appropriate to its activities. According to Mulyana \& Wijaya (2018), Comfort is a continuum of feelings from the most comfortable to the most uncomfortable assessed based on the perception of each individual on a matter where comfortable in certain individuals may be different from other individuals.

\section{g) Social Influence}

Jogiyanto (2007), defines social influence as the extent to which an individual perceives the interests that are trusted by others who will influence him using a new system. Venkatesh et al. (2003), states that in certain environments, the use of information technology will improve the status (image) of a person in the social system.

\section{Materials and Methods}

This type of research is descriptive qualitative with a case study approach. This research will be carried out in March 2020 at MSMEs located in Denpasar Bali, the data collection techniques used are observation, interviews, and documentation, the research informants are MSMEs in Denpasar. In this study using technical triangulation due to the same source but different techniques, namely through interviews and checking back through observation or documentation and using time triangulation because of seeing the development of the use of Mobile Payment at MSMEs from time to time. Data analysis techniques used in this study are Qualitative analysis used by researchers as stated by Hubberman \& Miles (1994) in (Sugiyono, 2017): namely data collection, data reduction, data presentation and the final step is concluding.

\section{Results and Discussions}

This research contributes to the literature by providing insight into the acceptance of Mobile Payment in Denpasar. By investigating the factors that influence the intention to use Mobile Payment, this study uses the Technology Acceptance Model (TAM) by adding variables of comfort and social influence. Although the emergence of Mobile Payment in Denpasar began to be adopted, especially in the retail and food industries, but this study provides empirical evidence regarding the factors that influence the intention to use Mobile Payment in Denpasar. The acceptance of Mobile Payment at UMKM has not been fully accepted, it has been proven through the results of an interview with Mr. Daniel who is the owner of Nada Juice said "70\% Cash and 30\% Mobile Payment bro" then Mr. Jerry who is the owner of Boss Seafood said "75\% Cash and 25\% Mobile Payment "and Mr. Komang Sujana who is the manager of the Akarsa Kokoro Restaurant said" ... 80\% Cash and 20\% Mobile Payment "so that from this it can be said that it has not been fully accepted, the use of Mobile Payment at MSMEs in Denpasar is more because of partnering with its application if for offline shopping rarely use the application and mostly use cash.

The Perception of Usefulness can be interpreted as the degree or level of confidence someone has in using a system that can improve the performance of its users. Based on the results of the interview gave a positive response to the use of Mobile Payment as Mr. Daniel said "... By using this OVO transactions become more practical and faster, bro. If you use cash, it is sometimes difficult to find fractions of change, using OVO, right? I don't need to think about the change, the application is also easy for buyers to use" Mr. Jerry who stated that "...... I was asked the benefits, the most felt was in the recording. Every day I like it when there are transactions via Ovo or Gopay either through the Grab / Gojek application or directly because I don't need to check any more money coming in. Moreover, the money goes directly into the account, so it's safer that employees don't have much money in the stall ...... .." Mr. Komang Sujana stressed "Payment methods are more varied, more up-to-date and more contemporary". So that the use of Mobile Payment provides positive benefits to business continuity at MSMEs.

Perception of Ease can be interpreted when someone believes that the system used is easy to operate, he will use the system, and vice versa. Based on the results of the interview gave a positive response to the use of Mobile Payment as Mr. Daniel said "It's easy, bro ... ... not complicated, customers just come then scan. Moreover, they collaborate with applications such as Ovo and Grab, Gopay, and Gojek ". Mr. Jerry stated that "It depends ... if the customer is a bit slang or millennial a little bit there is no difficulty using Ovo or Gopay. Moreover, Ovo or Gopay provide guidelines

Kusuma, P. O., \& Darma, G. S. (2020). Mobile payment transaction on MSMEs. International Research Journal of Management, IT and Social Sciences, 7(3), 104-109. https://doi.org/10.21744/irjmis.v7n3.926 
for use in the form of pamphlets so that consumers who have never used Ovo or Gopay can see the guide there. Also, the employees here are young people, they can help if there are customers who want to use Ovo or Gopay is having difficulty". Mr. Komang Sujana stressed "it is very easy to use Mobile Payment ..., the problem is common in older consumers because they are less literate about using technology".

Mobile Payment acceptance at MSMEs states that payment is Comfort to use. Based on the results of the interview gave a positive response to the use of Mobile Payment as Mr. Daniel said "If you say comfortable ..., yes, it's convenient, bro ..., just when I play the money, bro, because the money is directly transferred to the account entry $\mathrm{H}+$ 1 transaction So if most of it is through OVO, I have to wait for the money to come in. I will then withdraw the sales capital. Yes, it is rather disturbed there, bro ..., if the transaction via OVO is around Rp 100.000, I consider saving, bro". Mr. Jerry who stated that "the original is comfortable I provide many ways of payment, even though my stall just sells seafood so still up to date with the current environmental conditions. Even if there are customers I will explain if here (at my store) I can pay using Ovo or Gopay". Mr. Komang Sujana stressed "it is very convenient to provide Mobile Payment especially since the cashier program here also supports the use of Mobile Payment".

The role of Social Influence is to encourage the use of the system, hence the consumer's interest to use the product. Based on the results of the interview gave a positive response to the use of Mobile Payment as Mr. Daniel said "wow wow ..., I was overwhelmed with turning around money, $80 \%$ paid using Gopay or Ovo besides that my income is also now decreasing. Even though the juice is good for health, bro, in Corona, hehe ... ". Mr. Jerry who stated that "Now rarely there are consumers who come directly to the shop, mostly order using Gojek or Grab, $80 \%$ payment using Gopay or Ovo". Mr. Komang Suarjana stressed "The current condition of tourism is declining because of the spread of the COVID-19 virus, there has been a decline in income, but now it is often ordered via Grab and Gojek applications. Their payments also use Ovo or Gopay rarely use cash, compared to before, the payment is now $30 \%$ cash". The COVID-19 pandemic provides an impact on limiting activities outside the home, thus encouraging people to order food using the Gojek and Grab application and using Gopay and Ovo. It can be concluded that the more influence that an environment has on a prospective user of information technology to use new information technology, the greater the interest arising from the personal perspective user in using the information technology due to the strong influence of the surrounding environment (Nuryani et al., 2018; Leenders, 2002; Friedkin, 2001; Dholakia et al., 2004).

\section{Conclusion}

Based on the description of the discussion, it can be concluded that the acceptance of Mobile Payment cannot be fully accepted by MSMEs in Denpasar. Consumers use Mobile Payment because they have partnered with the application, if for offline shopping consumers rarely use and use more cash. Several factors cause MSMEs to provide Mobile Payment payments including Perception of Usefulness which means that the system can improve the performance of its users, then Perception of Ease which means believing that the system it uses is easy to operate so it will use the system, and vice versa., furthermore Perception of Comfort which is a state when the system can cause a sense following their desires that are supported also by the appropriate things. The influence of Social Influence can be interpreted as the effect an environment has on the System user to use it.

\section{Recommendation}

The implication that can be observed in this research is that besides the influence of perception of ease, usefulness, comfort, there is a social influence from the environment that causes the people's desire to use the system. There is a need for policies to accelerate the acceptance of Mobile Payment in the wider community, for example by collaborating with Mobile Payment Providers and Public Service Activities.

\section{Conflict of interest statement}

The authors declared that they have no competing interests.

\section{Statement of authorship}

The authors have a responsibility for the conception and design of the study. The authors have approved the final article.

Acknowledgments

We are grateful to two anonymous reviewers for their valuable comments on the earlier version of this paper. 


\section{References}

Blomstermo, A., Eriksson, K., Lindstrand, A., \& Sharma, D. D. (2004). The perceived usefulness of network experiential knowledge in the internationalizing firm. Journal of International Management, 10(3), 355-373. https://doi.org/10.1016/j.intman.2004.05.004

Davis, F. D. (1989). Perceived Usefulness. Perceived Ease of Use, and User Acceptance of.

Davis, F. D., Bagozzi, R. P., \& Warshaw, P. R. (1989). User acceptance of computer technology: a comparison of two theoretical models. Management science, 35(8), 982-1003. https://doi.org/10.1287/mnsc.35.8.982

Dholakia, U. M., Bagozzi, R. P., \& Pearo, L. K. (2004). A social influence model of consumer participation in networkand small-group-based virtual communities. International journal of research in marketing, 21(3), 241-263. https://doi.org/10.1016/j.ijresmar.2003.12.004

Friedkin, N. E. (2001). Norm formation in social influence networks. Social networks, 23(3), $167-189$. https://doi.org/10.1016/S0378-8733(01)00036-3

Guritno, S., \& Siringoringo, H. (2013). Perceived usefulness, ease of use, and attitude towards online shopping usefulness towards online airlines ticket purchase. Procedia-Social and Behavioral Sciences, 81, 212-216. https://doi.org/10.1016/j.sbspro.2013.06.415

Hubberman, A. M., \& Miles, M. B. (1994). Qualitative data analysis. Beverly Hills: Sage.

Iman, N. (2018). Is mobile payment still relevant in the fintech era?. Electronic Commerce Research and Applications, 30, 72-82. https://doi.org/10.1016/j.elerap.2018.05.009

Jogiyanto, H. M. (2007). Sistem informasi keperilakuan. Yogyakarta: Andi Offset.

Leenders, R. T. A. (2002). Modeling social influence through network autocorrelation: constructing the weight matrix. Social networks, 24(1), 21-47. https://doi.org/10.1016/S0378-8733(01)00049-1

Lintangsari, N. N., Hidayati, N., Purnamasari, Y., Carolina, H., \& Ramadhan, W. F. (2018). Analisis Pengaruh Instrumen Pembayaran Non-Tunai Terhadap Stabilitas Sistem Keuangan Di Indonesia. Jurnal Dinamika Ekonomi Pembangunan, 1(1), 47-62. https://doi.org/10.14710/jdep.1.1.47-62

Lu, Y., Yang, S., Chau, P. Y., \& Cao, Y. (2011). Dynamics between the trust transfer process and intention to use mobile payment services: A cross-environment perspective. Information \& management, 48(8), 393-403. https://doi.org/10.1016/j.im.2011.09.006

Mallat, N. (2007). Exploring consumer adoption of mobile payments-A qualitative study. The Journal of Strategic Information Systems, 16(4), 413-432. https://doi.org/10.1016/j.jsis.2007.08.001

Mulyana, A., \& Wijaya, H. (2018). Perancangan E-Payment System pada E-Wallet Menggunakan Kode QR Berbasis Android. Komputika: Jurnal Sistem Komputer, 7(2), 63-69. https://doi.org/10.34010/komputika.v7i2.1511

Nuryani, N. N. J., Satrawan, D. P. R., Gorda, A. A. N. O. S., \& Martini, L. K. B. (2018). Influence of human capital, social capital, economic capital towards financial performance \& corporate social responsibility. International Journal of Social Sciences and Humanities, 2(2), 65-76. https://doi.org/10.29332/ijssh.v2n2.128

Oliveira, A. S., Schlink, B. R., Hairston, W. D., König, P., \& Ferris, D. P. (2016). Induction and separation of motion artifacts in EEG data using a mobile phantom head device. Journal of neural engineering, 13(3), 036014.

Pratiwi, M. T., \& Indriani, F. (2017). Analisis Pengaruh Technology Readiness Terhadap Minat Menggunakan TCASH di Kota Semarang (Doctoral dissertation, Diponegoro University).

Saadé, R., \& Bahli, B. (2005). The impact of cognitive absorption on perceived usefulness and perceived ease of use in on-line learning: an extension of the technology acceptance model. Information \& management, 42(2), 317-327. https://doi.org/10.1016/j.im.2003.12.013

Safitri, D. A. (2015). Sustainability Report Terhadap Kinerja Keuangan Dan Pasar. Jurnal Ilmu \& Riset Akuntansi, 4(4), 1-15.

Slamet, R., Nainggolan, B., Roessobiyatno, R., Ramdani, H., \& Hendriyanto, A. (2016). Strategi Pengembangan UKM Digital dalam Menghadapi Era Pasar Bebas. Jurnal Manajemen Indonesia, 16(2), 136-147. https://doi.org/10.25124/jmi.v16i2.319

Sugiyono. (2017). Metode Penelitian Kualitatif (ed. Ke-3). Bandung:Alfabeta

Thompson, E. P., \& Osella, F. (1991). The moral economy of the English crowd in the eighteenth century.

Venkatesh, V., Morris, M. G., Davis, G. B., \& Davis, F. D. (2003). User acceptance of information technology: Toward a unified view. MIS quarterly, 425-478. https://doi.org/10.2307/30036540

Weisman, J. (1981). Evaluating architectural legibility: Way-finding in the built environment. Environment and behavior, 13(2), 189-204. https://doi.org/10.1177\%2F0013916581132004

Zhou, T. (2013). An empirical examination of continuance intention of mobile payment services. Decision support systems, 54(2), 1085-1091. https://doi.org/10.1016/j.dss.2012.10.034

Kusuma, P. O., \& Darma, G. S. (2020). Mobile payment transaction on MSMEs. International Research Journal of Management, IT and Social Sciences, 7(3), 104-109. https://doi.org/10.21744/irjmis.v7n3.926 